\title{
Global horizontal irradiation: spatio-temporal variability on a regional scale in the south of the Pampeana region (Argentina)
}

\author{
María Eugenia Fernández ${ }^{1,2, *}$, Jorge Osvaldo Gentilii, ${ }^{1,2}$, Ana Casado ${ }^{1}$, \\ Alicia María Campo 1,2
}

${ }^{1}$ Universidad Nacional del Sur, Departamento de Geografía y Turismo, Argentina

2 Consejo Nacional de Investigaciones Científicas y Técnicas, Argentina

* Corresponding author: eugenia.fernandez@uns.edu.ar

\begin{abstract}
The objective of this work is to analyze the spatio-temporal distribution of Global Horizontal Irradiation (GHI) on a regional scale and its relationship with frequent synoptic situations in the south of the Pampeana region (Argentina). It was verified that the latitudinal pattern of distribution of the GHI is modified in the region by cloud cover, which is in turn determined by the seasonal dynamics of action centers and the passage of fronts in summer and winter. The South America Monsoon System (SAMS) defines differential situations of cloudiness and rainfall in the region, which affect GHI. GHI increased successively between the decades 1981-2010, a factor associated with the variability of rainfall that characterizes the region.
\end{abstract}

\section{KEYWORDS}

solar energy; atmospheric pressure; synoptic situations; cloudiness; spatial patterns

Received: 6 November 2020

Accepted: 20 October 2021

Published online: 24 November 2021

Fernández, M. E., Gentili, J. O., Casado, A., Campo, A. M. (2021): Global horizontal irradiation: spatio-temporal variability on a regional scale in the south of the Pampeana region (Argentina). AUC Geographica 56(2), 220-233

https://doi.org/10.14712/23361980.2021.14

(C) 2021 The Authors. This is an open-access article distributed under the terms of the Creative Commons Attribution License (http://creativecommons.org/licenses/by/4.0). 


\section{Introduction}

Solar radiation is the main source of energy for all climatic processes and the determining factor of the intensity and distribution gradients of different climate elements (such as temperature, humidity and atmospheric pressure, among others). Thus, radiation is the ultimate cause of climate differences and affects all climate-related phenomena (Patton, Alexander, and Kramer 1978).

Solar radiation reaching the earth surface depends on solar height, day length, atmospheric conditions and terrain topography. While site conditions (latitude and topography) determine the intensity and duration of insolation, the earth's atmosphere filters incident radiation by absorption, diffusion and reflection processes (Abal 2012; Patton, Alexander, and Kramer 1978; Oke et al. 2017; Sengupta et al. 2017). About the theoretical concepts regarding solar radiation, this paper uses the following terms: direct radiation, diffusse radiation and Global Horizontal Irradiation (GHI). Direct radiation is that which is received directly from the Sun without suffering any atmospheric dispersion. Diffuse radiation is the one the surface receives after being deflected by discrete particles present in the atmosphere. GHI is the geometric sum of direct and diffuse radiation received on a surface (Hermosillo Villalobos, Gudiño Ayala, and Mendoza Ramírez 1995; Habte et al. 2017).

Solar radiation has become an object of growing scientific interest due to its potential for sustainable energy optimization. Photovoltaic electricity production is one of the most recent renewable energy sources with the widest field of application. However, the use of the solar resource depends on the knowledge of the intensity and distribution of solar radiation received in a given space, as well as its temporal variation (Sengupta et al. 2017; Vera Mella and Baldasano Recio 2005). Regardless of site conditions the dynamics of atmospheric action centers and cloud type and cover associated are the main causes of the spatio-temporal variability of solar radiation (Weber 1994; Matuszko 2012; Fernández, Gentili, and Campo 2018). Consequently, the interaction of solar radiation and its components with action centers dynamics has been increasingly studied by numerous researchers around the world (Jerez and Trigo 2013; Pozo-Vázquez et al. 2004; Tomson and Hansen 2010; Urban, Migała, and Pawliczek 2017; Fernández, Gentili, and Campo 2018). The study of the spatio-temporal variability of the solar resource and its representation by way of theme maps constitutes a basic management tool useful when evaluating and executing measures aimed at sustainable energy development (Gueymard and Wilcox 2011; Habte et al. 2017). Numerous investigations are focused on the study of solar radiation components and their spatio-temporal variability, mainly regarding its use as an energy resource (De Miguel et al. 1994; Gallegos and Righini
2002; Gómez-Tagle Chávez and Chávez Huerta 2004; Lohmann et al. 2006; Raichijk et al. 2006a; Raichijk et al. 2006b; Grossi Gallegos and Spreafichi 2007; Lave and Kleissl 2010; Grossi Gallegos et al. 2010; Gueymard and Wilcox 2011; Davy and Troccoli 2012; Sanchez-Lorenzo et al. 2012; Righini and Aristegui 2013; Gueymard 2012; Raichijk 2012; Raichijk 2013; Gil et al. 2015).

One of the greatest challenges in the study of radiation in terms of resources relates to the high cost of measurement instruments and consequent unavailability of continuous records in space and time in the long term. This challenge involves Argentina and numerous regions in other developing countries, where the availability of solar radiation records is often limited (Raichijk, Grossi Gallegos, and Righini 2006; Ramirez Camargo et al. 2015). In this situation, it is necessary to look for alternative data sources in order to assess the variability of the solar resource in different territories. Historically, the data on sunshine hours have been used to estimate GHI (Löf, Duffie, and Smith 1966; Hay 1979; Benson et al. 1984; Román, Bilbao, and de Miguel 2014; Assi and Jama 2010; Sengupta et al. 2017; Argungu, Dabai, and Scholar 2017). The use of numerical models for GHI studies emerges as an alternative, reanalysis being one of the most used (Schroeder et al. 2009; Linares-Rodríguez et al. 2011; Lohmann et al. 2006; Ramirez Camargo et al. 2015). In this context, our objective in this study has been to analyze the spatio-temporal distribution of $\mathrm{GHI}$ at a regional level and its relation with frequent synoptic situations in the south of the Pampeana region (Argentina). From the environmental climate and given the growing energy requirements of urban centers, it is necessary to assess the renewable energy potential as a possibility of energy matrix diversification at a regional and local level.

\section{Materials and methods}

\subsection{Study area}

The study area includes the southern sector of the Argentine Pampeana region. It covers the south of Buenos Aires province, the east of La Pampa province and a sector of the northwest of Río Negro province (Fig. 1)

The climate in the south of the Pampeana region is temperate. Within this temperate climate a difference can be established between the temperate transition to arid climate in the South and the temperate oceanic climate in the eastern sector near the sea (García 2013). Regional atmospheric circulation is controlled by large-scale systems influencing southern South America; namely the semi-permanent anticyclones from the Atlantic (South Atlantic High, SAH) and Pacific (South Pacific High, SPH) oceans (Chiozza and Figueras 1982; Grimm, Barros, and Doyle 2000) (Fig. 2). Furthermore, the studied sector is located 


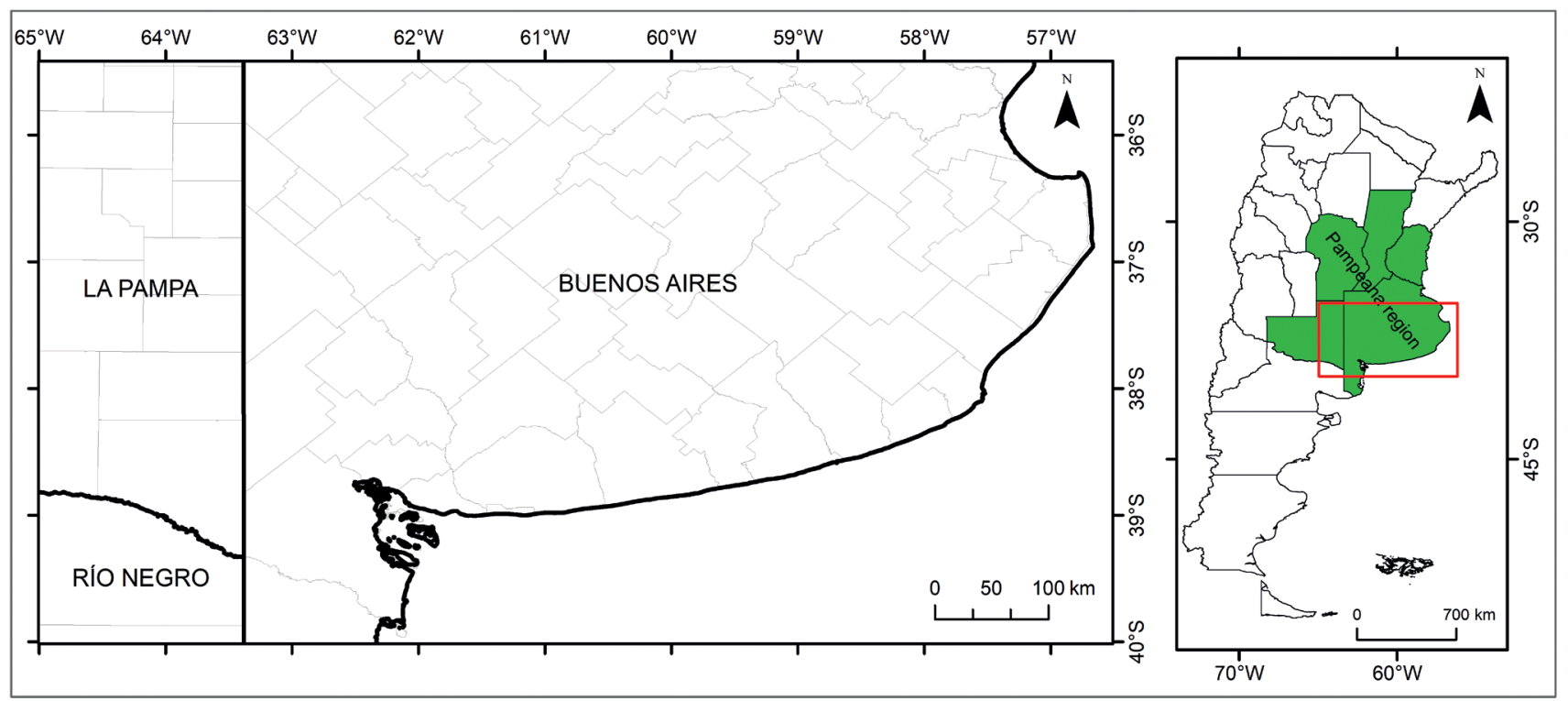

Fig. 1 Study area.

in one of the areas with the highest frequency of passage of migratory anticyclonic systems (García 2013; Celemín 1984). These systems enter the territory in a west-east direction and are characterized by causing various weather conditions associated with their passage (Celemín 1984; Alessandro 1998). In winter, the influence of cold and humid air arising from cellular detachments of the High Pressures of the South Pacific Ocean stands out (García 2013; Sinclair 1996; Mendes 2006; Ambrizzi and Pezza 1999; Bruniard 1981; Pezza and Ambrizzi 2003; Celemín 1984; Alessandro 1998). In summer and within the continent, the continental Tropical air masses (cT) inhibit precipitation, generating droughts and loss of energy due to night cooling. In the coastal areas of the Pampeana region, maritime Tropical air masses (mT) dominate. These emerge from the western edge of the South Atlantic Anticyclone, its entry to the continent favors the development of cloudiness and precipitation and the summer storms that occur in the region (Fig. 2) (Scian 2010; Celemín 1984; Bejarán and Camilloni 2003). The regional thermal spatial distribution has a rather homogeneous character and is mainly determined by geographical factors on a regional scale, such as altitude, proximity to the sea or advective movements. The continental influence defines the values of annual thermal amplitude and the occurrence of frosts (Campo de Ferreras, Capelli de Steffens, and Diez 2004).

In the southern Pampeana region, rainfall has a marked spatio-temporal variability. Precipitated amounts decrease from northeast to southwest, with differences that exceed $400 \mathrm{~mm}$ (Gabella, Zapperi Paula, and Campo Alicia 2010; García 2013). Likewise, the presence of a rainy season extending from October to March and a relatively dry season from May to September can be observed (Casado and Campo 2019; Gabella, Zapperi Paula, and Campo Alicia
2010). Although previous studies found maximum peaks in spring and autumn (Capelli de Steffens, Piccolo, and Campo de Ferreras 2005; Campo de Ferreras, Capelli de Steffens, and Diez 2004), recent studies in the region (Gabella, Zapperi Paula, and Campo Alicia 2010) and at a local level (Gentili and Gil 2013) identify summer as the rainiest season. This coincides with the increase in summer precipitation registered in large sectors of the American continent since 1970 (Casado and Campo 2019; Liebmann et al. 2004). Summer rainfall is mainly caused by convective activity and the development of frontal systems, while in the dry season precipitation is linked to frontal systems (cold and warm), frontal waves and cyclogenesis processes (P. Zapperi et al. 2007; P. A. Zapperi et al. 2006). About the precipitation types, Sarochar et al. (2005) found that between January 1995 and December 2001 , convection produced about $75 \%$ of the precipitation, the remaining $25 \%$ due to stratiform cloudiness. Precipitation of stratiform origin only showed greater weight in April and October. Convective precipitation is associated with cumuliform cloudiness (cummulus congestus and cumulonimbus). This result is consistent with more recent investigations (Sarochar 2018). Regarding cloudiness in the study area, Fernández et al. (2018) analyzed its spatial distribution in the period 2001-2015. The authors found higher percentages (31.6-38\%), of overcast skies in the northeast of the study area. The highest clear skies percentages were found in the west of the study area and they decreased in a west-east direction. This is in good agreement with the decrease in precipitations amounts stated earlier. At interannual scale, rainfall in the region has great variability which allows differentiating between dry and wet periods (Bohn, Piccolo, and Perillo 2011; Campo, Ramos, and Zapperi 2008; Scian 2010; Campo de Ferreras, Capelli 


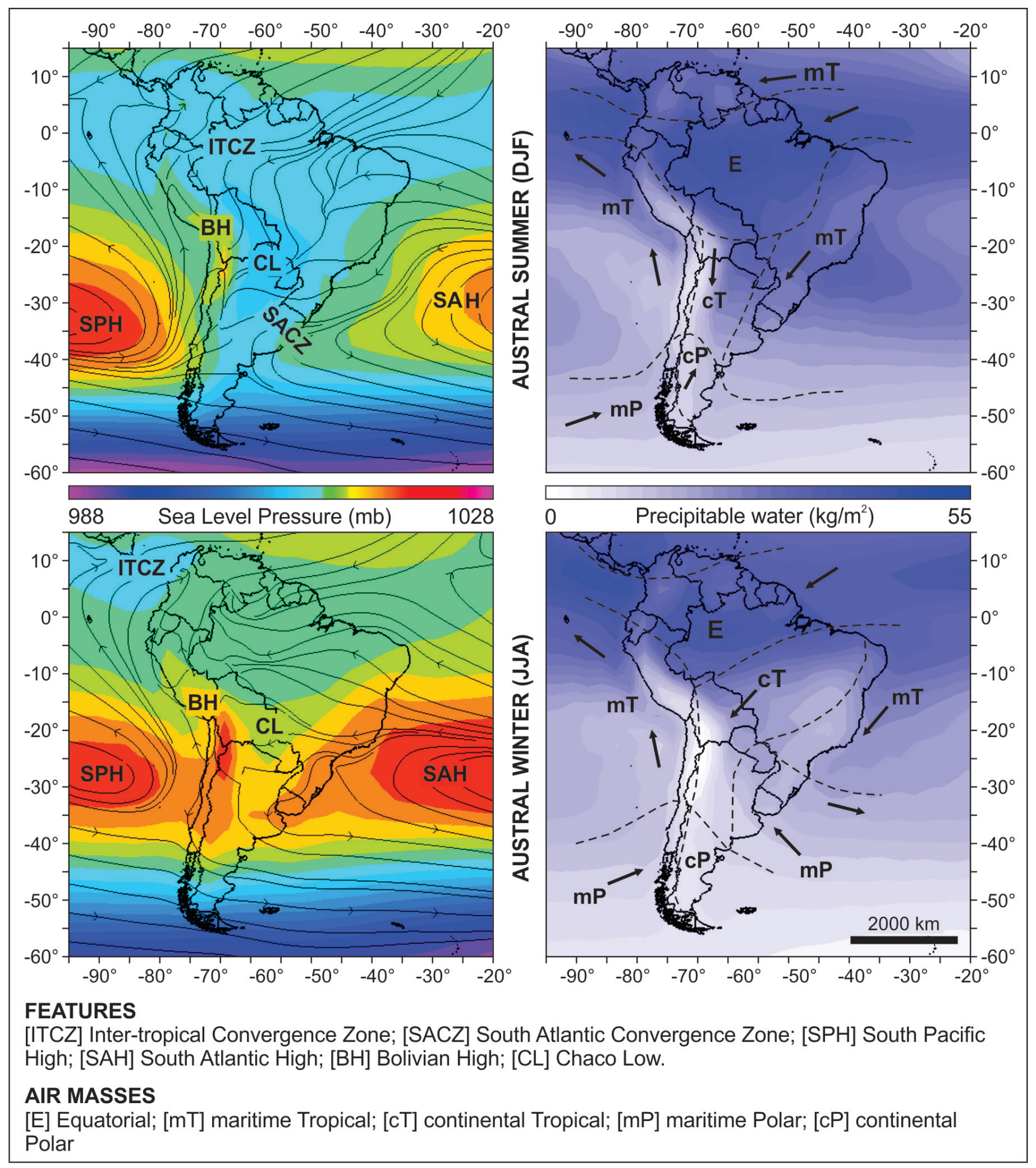

Fig. 2 Seasonal patterns of atmospheric circulation and precipitable water over South America and adjacent oceans.

Source: Sea level pressure, surface wind streamlines, and precipitable water maps were derived from long-term (1981-2010) monthly means of the NCEP/NCAR Reanalysis. Fronts and air masses were based on Campo et al. (2004). Modified from Casado (2013).

de Steffens, and Diez 2004; Ferrelli et al. 2012; Gentili 2012; P. A. Zapperi 2012). This phenomenon can be related to the El Niño Southern Oscillation (ENSO, for its acronym in English) (Ferrelli 2016; Grimm, Barros, and Doyle 2000; Grimm 2011), although a great complexity of atmospheric processes is also involved, such as sea surface temperature anomalies in the South Atlantic Ocean or variations in the convective activity of the South Atlantic Convergence Zone (Doyle and Barros 2002; Barros et al. 2000; Casado and Campo 2019).

\subsection{Data collection and analysis}

This work uses Global Horizontal Irradiation (GHI, MJ $\mathrm{m}^{2} \mathrm{~d}^{-1}$ ) gridded data extracted from the Climate 
Forecast System Reanalysis (CFSR) of the National Center for Environmental Prediction (NCEP) (Saha et al. 2010). The selected area has $365,500 \mathrm{~km}^{2}$ and includes 369 points evenly distributed every $0.25^{\circ}$ lat/long. Average annual radiation values were calculated for the 1981-2010 period, decadal means (1981-1990; 1991-2000; 2001-2010) and seasonal means (DJF; JJA) for each decade as well as for the entire period. This provided 12 data series for each of the points extracted. The data matrix $(369 \times 12)$ was incorporated into a Geographic Information System (ArcGIS, ESRI@) to obtain spatial distribution maps of each of the data series. The Kriging interpolation method and a $2 \mathrm{~km}$ mesh were used.

On the other hand, the NCEP/ NCAR Reanalysis products derived from the Physical Sciences Laboratory (NOAA) were used to compare the spatio-temporal variation of the GHI with the dynamics of action centers in the area and period considered. Within the range of available data, surface variables $(.995$ sigma level) were selected. These include monthly means and long term means of sea level pressure $(\mathrm{hPa})$, uwind $\left(\mathrm{m} \mathrm{s}^{-1}\right)$, and vwind $\left(\mathrm{m} \mathrm{s}^{-1}\right)$ for the period 1981-2010. The visualization, treatment and statistical analysis of the pressure and wind series were carried out in the Integrated Data Viewer program (IDV, Unidata).

\section{Results and discussion}

The mean annual distribution of atmospheric pressure values at sea level and surface winds in Argentina (Fig. 3A) and in the south of the Pampeana region
(Fig. 3B) were analyzed. Figure 3A shows the presence of the Chaco Low (CL), SPH and SAH, whose pressures exceed $1020 \mathrm{hPa}$ (Scian 2010). SAH is responsible for the downward pressure gradient in an east-west direction, originating the east and northeast component winds of the study area (Fig. 3B) and air masses loaded with humidity. Consequently, temperate climates with oceanic influence typical of the south pampeana region have a higher frequency of rainfall, low potential evapotranspiration and conditions leading to fog formation. In the coastal areas of the Pampeana region dominate maritime Tropical air masses $(\mathrm{mT})$ which emerge from the western edge of the South Atlantic Anticyclone, whose entry to the continent favors the development of cloudiness and precipitation and the summer storms that occur in the region (Capelli de Steffens, Piccolo, and Campo de Ferreras 2005; Scian 2010; Celemín 1984; García 2013). As air masses advance over the continent, weather conditions are characterized by scarce rainfall, lower relative humidity values and cloudiness (Capitanelli 2008).

The annual distribution of GHI in the study area (Fig. 4) corresponds to the synoptic characteristics of the analyzed sector. The variable was observed to have an increasing gradient in an east-west direction, which coincides with the increase of the continental influence. Annual average values between 19.5 and $16.5 \mathrm{MJ} \mathrm{m}^{2}$ of GHI were estimated for the period 19812010. Coastal zones in the eastern Buenos Aires province sector have lower GHI values than the rest of the study area. The southern sector of Buenos Aires province, despite its coastal location, has radiative conditions similar to the surrounding continental areas.

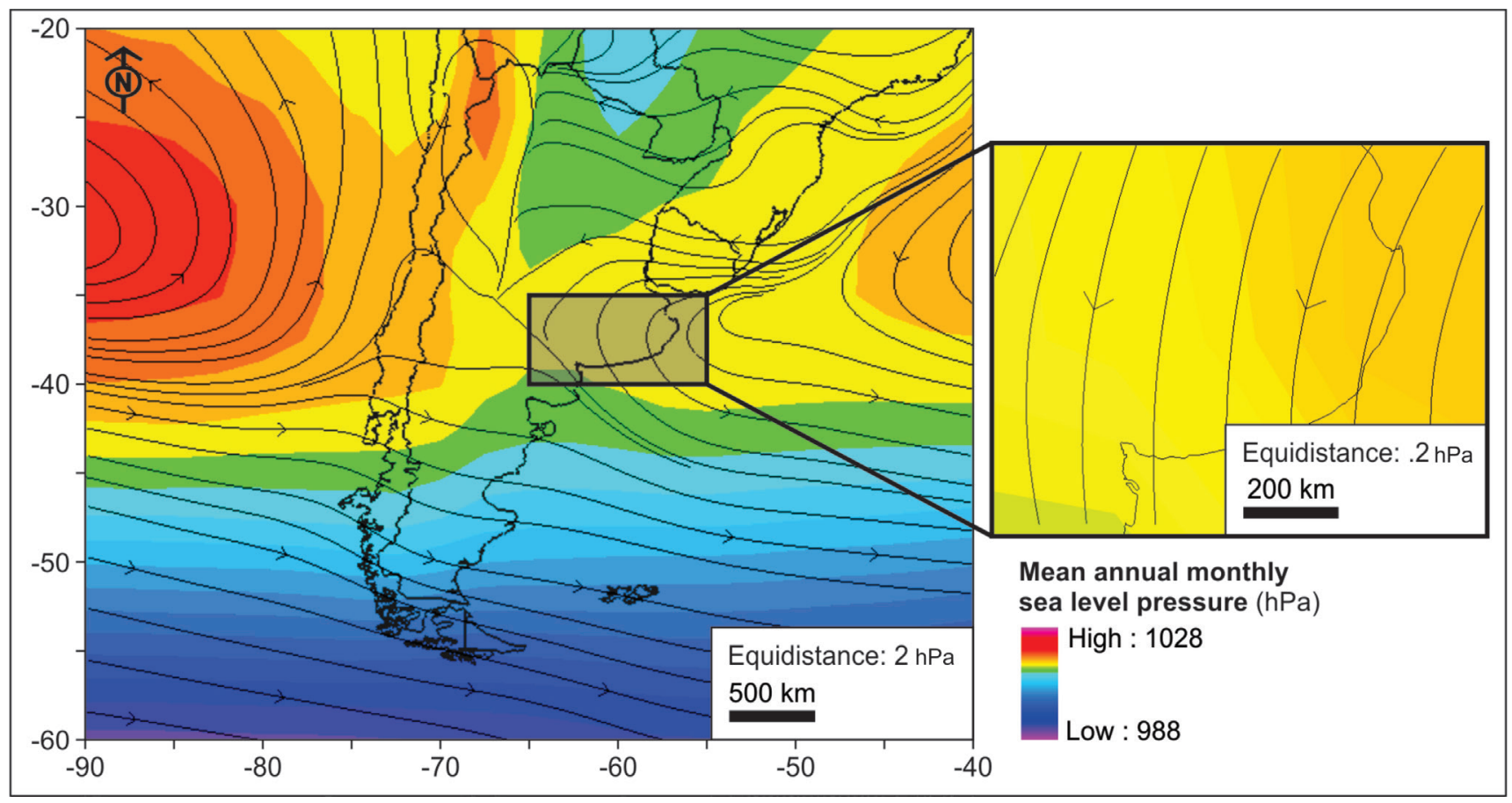

Fig. 3 Mean annual sea level pressure (hPa) and surface wind streamlines ( $\left.\mathrm{m} \mathrm{s}^{-1}\right)$ for the period 1981-2010. 

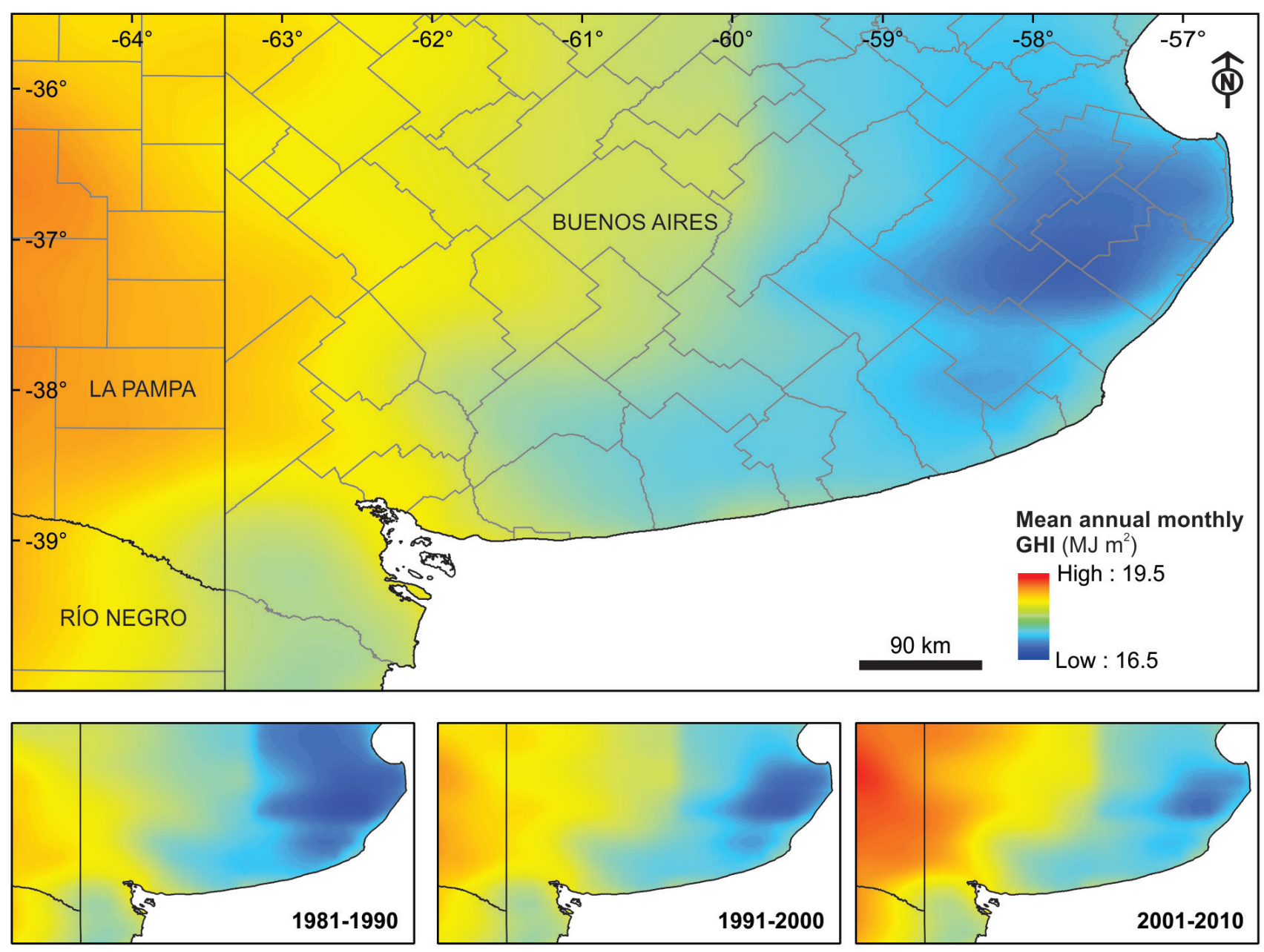

Fig. 4 Distribution of the mean annual Global Horizontal Irradiation (GHI) in the south of the Pampeana region (1981-2010).

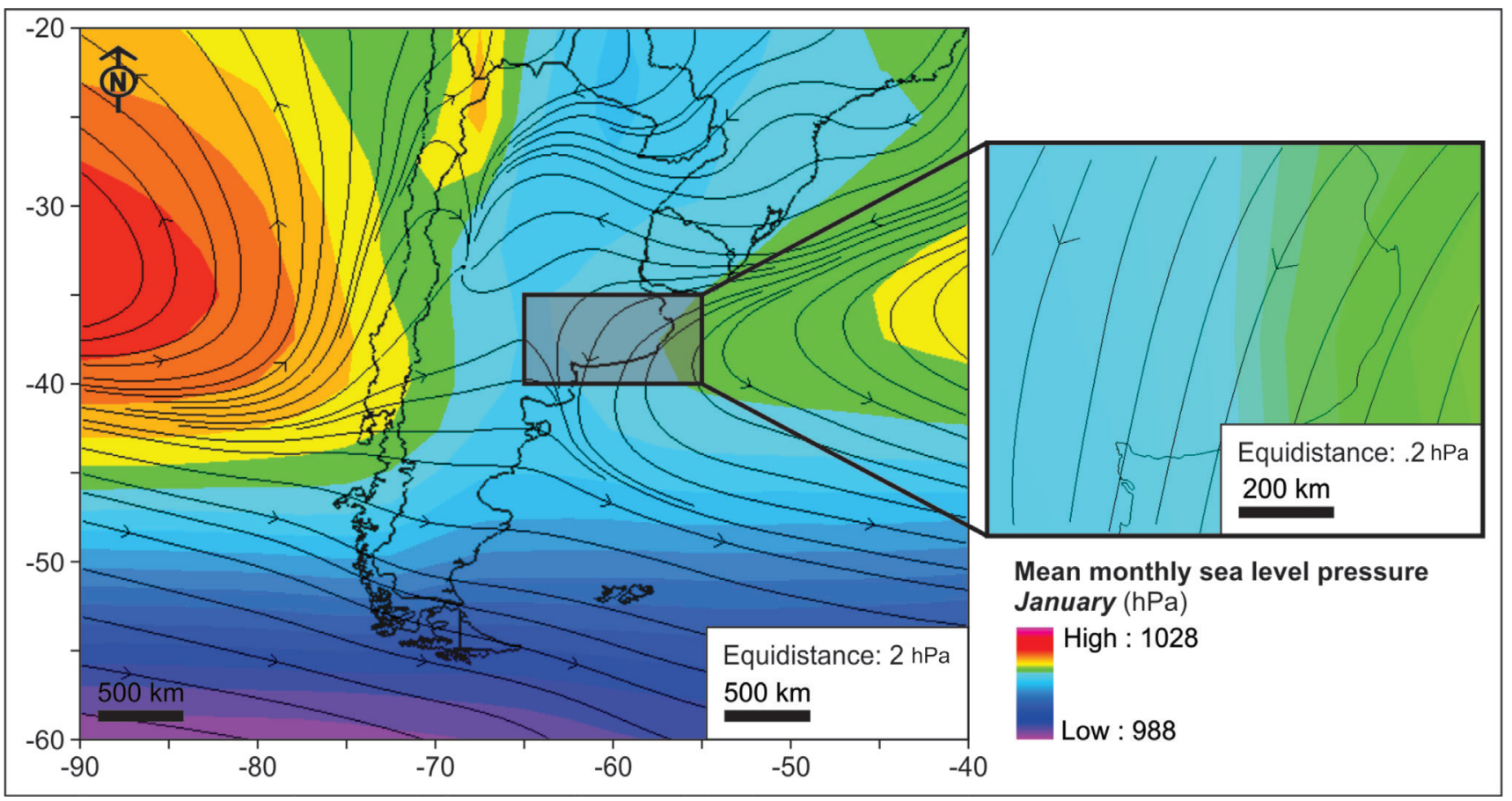

Fig. 5 Mean monthly sea level pressure $(\mathrm{hPa})$ and surface wind streamlines $\left(\mathrm{m} \mathrm{s}^{-1}\right)$ during austral summer for the period 1981-2010. 
The regional atmospheric circulation that defines the greater frequency of winds from the North, Northwest and West and the influence of continental Tropical air masses (cT) inhibit the formation of clouds and precipitation, which explains the greater availability of GHI in the sector (Capelli de Steffens, Piccolo, and Campo de Ferreras 2005). Regarding interdecadal analysis, the distribution of the variable can be linked to the variability of rainfall that characterizes the region. Although GHI is directly influenced by cloud cover and the presence of clouds does not necessarily imply the occurrence of precipitation, they are considered to be weather elements with closely linked dynamics. Droughts in Argentina are directly associated with persistent anticyclonic conditions and a change in cloud cover of an area may be indicative of the beginning of this type of event (Piccolo, Capelli de Steffens, and Campo de Ferreras 2002). It can be observed that in the decade 1991-2000, all sectors located north of the area registered higher GHI values compared to 1981-1990. Furthermore, maps show that GHI increased successively in the region between the decades 1991-2000 and 2001-2010. The area with higher GHI values expanded towards the northeast and the areas with lower GHI were reduced in the eastern sector. In the decade 2001-2010, the western sector of the study area shows the highest GHI value estimated. These findings are in agreement with the trends found in rainfall volumes on a regional scale. Campo et al. (2008) registered the existence of two humid periods between 1976 and 1988 and between 1992 and 1997, associated with El Niño events of the El Niño-Southern Oscillation (ENSO) phenomenon. On the other hand, the period 2004-2009 is defined as one of the most important droughts since 1950 (Bohn, Piccolo, and Perillo 2011; Ferrelli 2010; Scarpati and Capriolo 2013). By 2005, the drought had already affected $46 \%$ of Buenos Aires province and in 2008 the national government declared the area Agricultural Disaster. The most affected areas were concentrated in the south of the province, including Bahía Blanca (Andrade, Laporta, and Iezzi 2009; Scarpati and Capriolo 2013).

The summer situation (Fig. 5) is generally defined by the presence of a low thermal pressure system in northern Argentina (CL), as well as low pressure centers (corresponding to the subpolar low pressure belt) south of Patagonia and the semi-permanent anticyclones of the Pacific and Atlantic oceans (Fig. 5A), which have a more northern position approximately $5^{\circ}$ latitude closer to the Equator in winter) - due to the displacement of the climate system as a whole towards the south during summer (Garreaud and Aceituno 2007; Scian 2010; Minetti 2007; Hoffmann 1992; Inzunza 2012). The summer atmospheric dynamics in the study area is partly defined by the occurrence of the South America Monsoon System (SAMS), an atmospheric phenomenon related to annual rainfall variability (Vera et al. 2006; Marengo et al. 2012;
Mendonça 2017; Zhou and Lau 1998; Romero Aravena et al. 2011; González and Barros 2001). The SAMS comprises a complex spatial structure fundamentally composed of the Intertropical Convergence Zone (ITCZ), the Bolivian High (BH) and the Chaco Low (CL) (Romero Aravena et al. 2011; Franco et al. 2017). In the Amazon, strong summer convective heating results in the generation of $\mathrm{BH}$, associated with the $\mathrm{CL}$ centered over northern Argentina, which also intensifies during summer. The increase in continental convection is related to ITCZ migration (from $14^{\circ} \mathrm{N}$ in August-September to $5^{\circ} \mathrm{S}$ March-April) and the predominance of east-northeast winds (Romero Aravena et al. 2011). Thus, during summer the east-northeast circulation brings tropical air masses from Brazil to central Argentina; the main cause of rainfall in the study area (González and Barros 2001; Celemín 1984; Doyle and Barros 2002). Figure 5 shows that, while the $\mathrm{N}$ zone of the study area is fundamentally influenced by E-NE component winds (carriers of humidity and precipitation), the SW zone has a greater influence from the $\mathrm{W}$ winds that, due to their continental route are carriers of dry air masses. This atmospheric dynamic defines differential situations of cloudiness and precipitation in the study area. On the other hand, $\mathrm{SAH}$ is located on the coasts of Brazil and Uruguay and extends a high pressure zone to the east of Buenos Aires province (Fig. 5). As a consequence, Atlantic air masses, which have a more southern influence, penetrate the continent loaded with humidity contributing to the increase in cloud cover and the consequent decrease in GHI in the eastern sector of the study area. As they move across the continent air masses lose moisture and cloud cover decreases. According to the most frequent summer synoptic situations stated by Celemín (1984), the advance of cold fronts from Patagonia to the northeast may allow the formation of lines of instability in several sectors of Buenos Aires, which define bad weather conditions, cloudiness and rainfall in the region (P. Zapperi et al. 2007; Casado and Campo 2019; Gabella, Zapperi Paula, and Campo Alicia 2010; Celemín 1984; Rubí Bianchi and Cravero 2010).

The average summer regional distribution of GHI (Fig. 6) ranges between 25 and $29 \mathrm{MJ} \mathrm{m}^{2}$. Interdecadal analysis shows GHI values increased throughout the analyzed area between 1981 and 2010. GHI distribution in the region coincides with periods of water excesses that characterized Argentina until 2003, subsequently followed by a drier period. The southeast zone of the study area has lower GHI values than the central zone. A descending gradient is observed in a west-east direction in the northern sector of the study area. On the other hand, the continental zone has lower GHI values than the coastal zone in the south of the study area. As with annual distribution, the relationship between GHI distribution and the continentality of the analyzed area is evident. On the other hand, common synoptic situations in the warm 

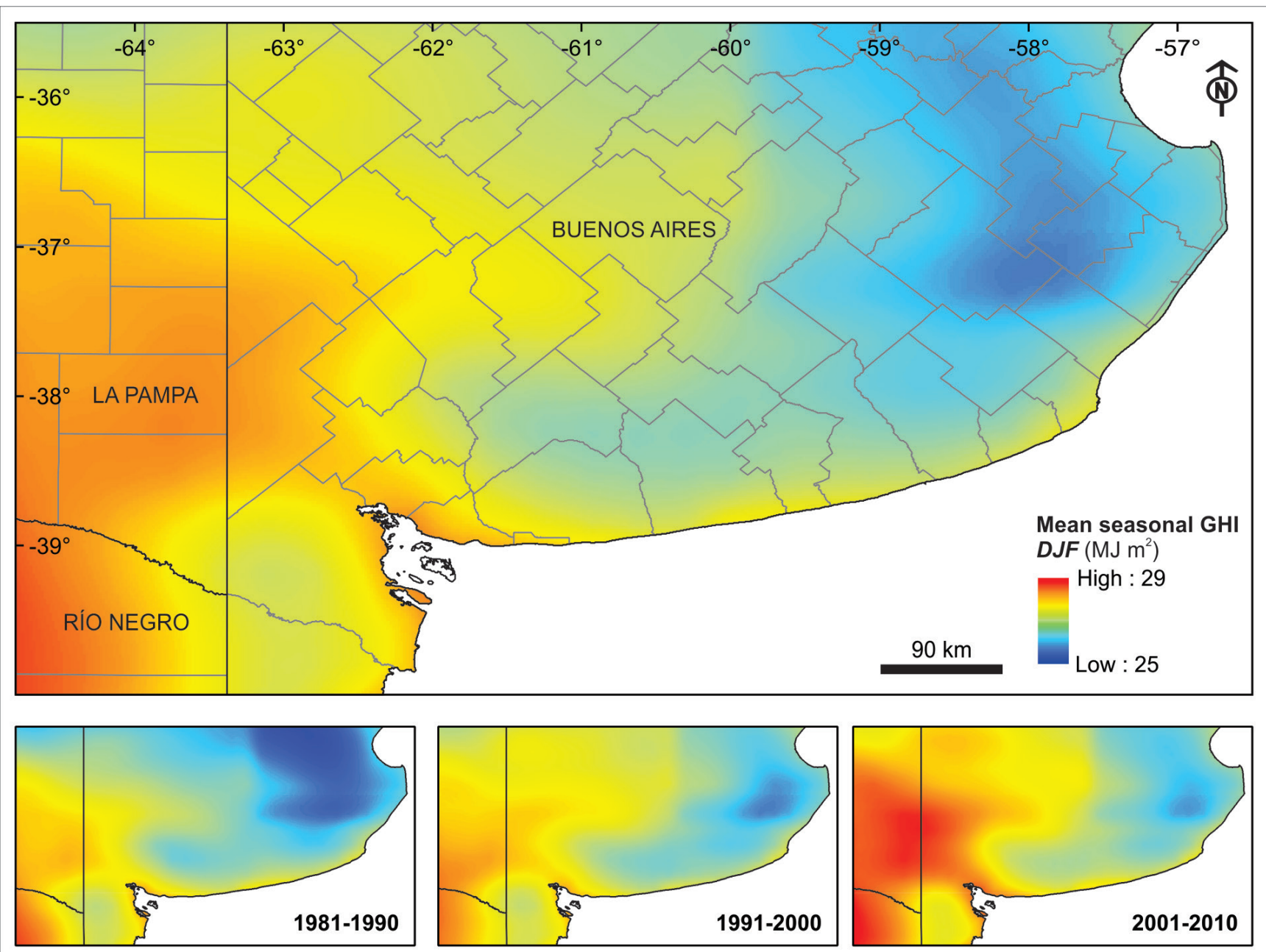

Fig. 6 Distribution of the seasonal mean Global Horizontal Irradiation (GHI) (DJF) in the south of the Pampeana region (1981-2010).

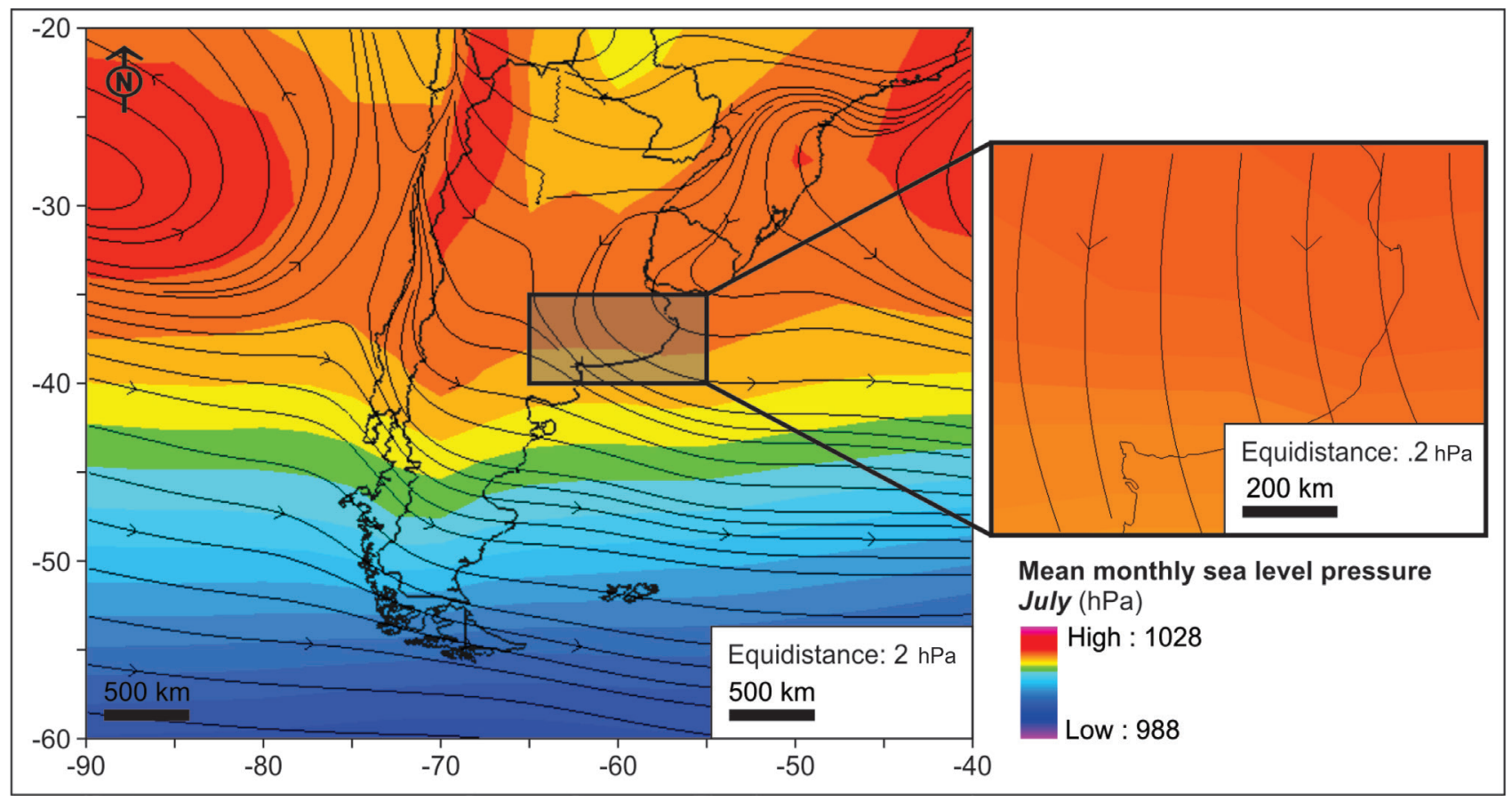

Fig. 7 Mean monthly sea level pressure (hPa) and surface wind streamlines $\left(\mathrm{m} \mathrm{s}^{-1}\right)$ during austral winter for the period 1981-2010. 
season are directly related to rainfall occurrence and cloud cover in the study area, so GHI distribution can be explained by analyzing the typical summer synoptic conditions of the region.

The winter distribution (1981-2010) of atmospheric pressure values at sea level and associated winds in Argentina (Fig. 7A) and in the south of the Pampeana region (Fig. 7B) were analyzed. SPH and $\mathrm{SAH}$ can be seen to migrate north as a consequence of the displacement of the warming zone. The influence of air masses loaded with humidity from SAH is reduced in the NE zone of the study area, so a downward pressure gradient is observed in the NE-SW direction, with the presence of high pressures in the center of the country. CL is weakened during winter months, so the influence of westerly winds is greater in the study area, unlike the summer period. As stated by Celemín (1984), during winter the passage of cold fronts is related with the presence of middle clouds, generally Altocumulus (AC), Altostratus (AS) and when rainfall starts, Nimbostratus (NS). The anticyclonic presence in the center of the country after the passage of the cold front defines clear skies in the northwestern sector of the south Buenos Aires province.

The occurrence of Sudestadas can be associated with GHI distribution in the study area. The Sudestada is a weather condition characterized by the occurrence of strong and persistent winds from the southeast sector, usually accompanied by rains affecting the coasts of the Buenos Aires province (Celemín 1984; Escobar, Vargas, and Bischoff 2004; Pizarro et al. 2007; Ferreras, Moresino, and Huamantinco 2004; Ramos and Campo 2008; Servicio Meteorológico
Nacional 2010). The Sudestada commonly extends from 1 to 3 days and begins with a cold front passage that crosses Patagonia and Buenos Aires province and by the action of a high pressure system located over Patagonia or southern Buenos Aires. This center is a cell detachment of the semi-permanent South Pacific anticyclone. From this action center, other smaller anticyclones called migratory are periodically detached and enter Argentine territory moving towards the east to later join the South Atlantic Anticyclone (Alessandro 1998; Aguirre et al. 2021). Each of the positions of the migratory anticyclones will define particular weather conditions and wind directions (Celemín 1984). When the cold front stops in the north Argentine territory and becomes stationary, a low pressure center (frontal wave) can form in the north of Uruguay, which will attract winds emitted by the migratory anticyclone located in north Patagonia. As a consequence, the province of Buenos Aires will receive winds from the east-southeast with speeds of 20 to 30 knots and with gusts of 40 to 50 knots, with the possibility of rain, drizzle and sometimes thunderstorms in the coastal areas. In this way, the occurrence of the Sudestada will define clear sky situations for continental zones of the study area, while in coastal zones clouds and rainfall will occur. This analysis coincides with findings by other authors (Casado and Picone 2018; Penalba and Vargas 2004), who argue that the west Buenos Aires province exhibits a more marked dry season, which can be interrupted by the action of frontal systems (P. A. Zapperi et al. 2006). Celemín (1984) developed a model for anticyclone tracks in Argentina based on a historical compilation of record anticyclones (Fig. 8). Recent investigations

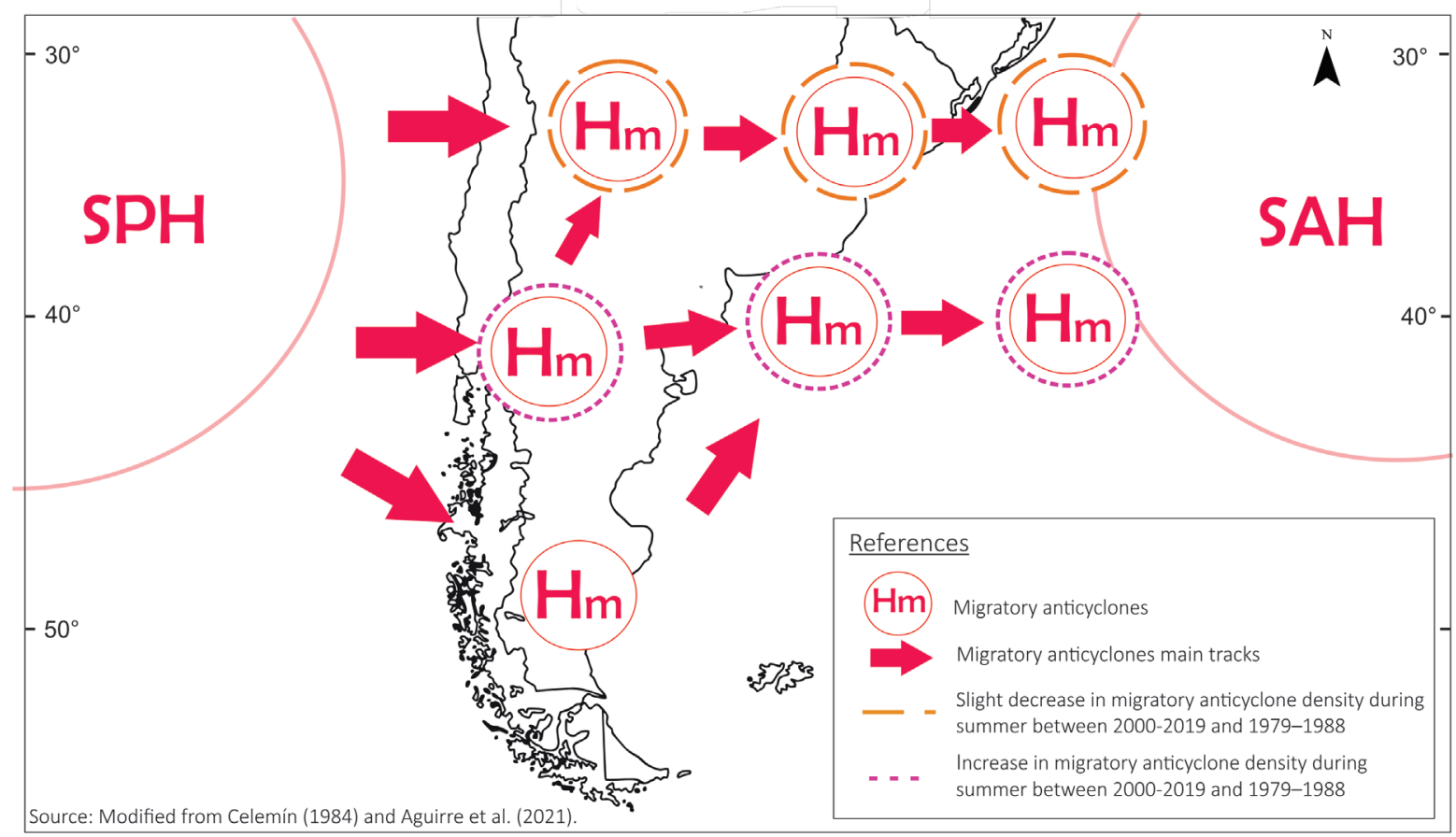

Fig. 8 Stationary and migratory anticyclones scheme in the southern area of South America. 
(Aguirre et al. 2019; 2021) analyzed the average density of anticyclones in the Southern Hemisphere. Aguirre et al. (2021) documented the difference between the density of the 2000-2019 decade and the first decade of the data (1979-1988). The authors found that during summer an increase in migratory anticyclone density was noticeable around $40^{\circ} \mathrm{S}$, while a slight decrease was observed between $27^{\circ} \mathrm{S}$ and $38^{\circ}$ S. Nevertheless, minor changes in density of migratory anticyclones were found during winter. It can be inferred that around $40^{\circ} \mathrm{S}$, during the advance of migratory anticyclones between the firsts two positions of the main track situated around $40^{\circ} \mathrm{S}$ (Fig. 8), eastern flanks of the action centers that coincide with the coastal zones are those that present the maximum percentage of sky covered, with between 6 and 8 oktas of medium clouds and 2 and 4 oktas of low clouds (Celemín 1984).

GHI spatial distribution in the south of Buenos Aires during the winter season (Fig. 9) shows an increasing gradient in a southeast-northwest direction, with values that range between 8 and $11 \mathrm{MJ} \mathrm{m}^{2}$. The lower spatial variability with respect to the summer situation is in agreement with reports by other researchers, a factor related to solar flux reduction and greater occurrence of totally cloudy skies (Grossi Gallegos 1997; Hay 1984). The distribution is observed to have a pattern mainly influenced by the occurrence of frequent synoptic situations in the mentioned season, which define winter cloudiness patterns. These are fundamentally two: the advance of cold fronts on Argentine territory and the Sudestada situation (Celemín 1984). GHI spatial distribution during the winter season presents an ascending gradient in a southeast-northwest direction, approximately perpendicular to the direction of advance of fronts (and associated cloud cover) which continuously cross the country (Rubí Bianchi and Cravero 2010).

\section{Conclusions}

GHI spatio-temporal distribution in the south of the Pampeana region was analyzed. The analysis was approached at a regional scale, identifying its variability based on the synoptic conditions and associated cloud cover. Regionally, it was verified the latitudinal pattern of GHI distribution is modified by cloud cover, determined by seasonal dynamics of the action centers and the passage of fronts, which continuously
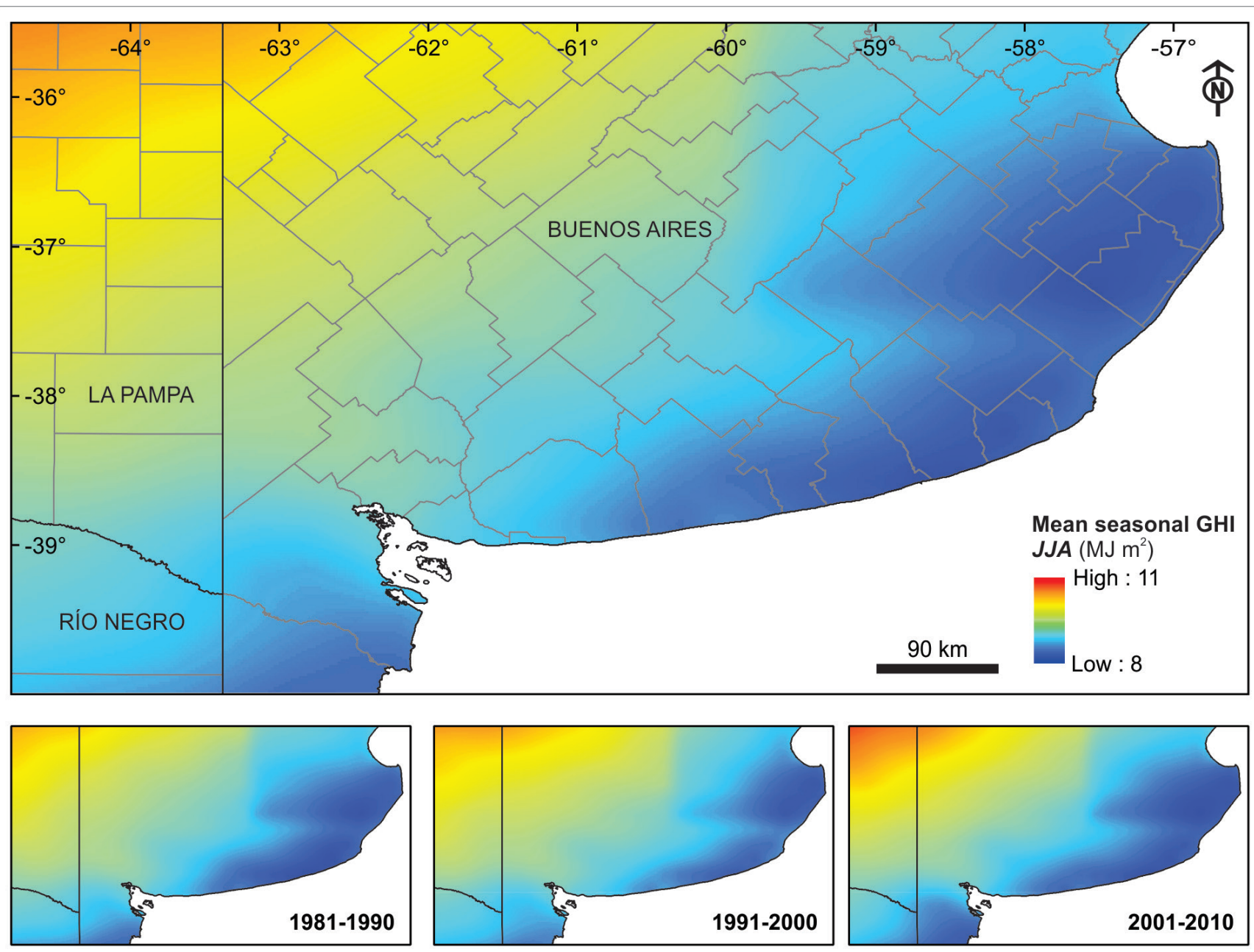

Fig. 9 Distribution of seasonal mean Global Horizontal Irradiation (GHI) (JJA) in the south of the Pampeana region (1981-2010). 
cross the Argentine territory. Among climatic features involved, the SAMS defines differential situations of cloudiness and rainfall in the region, which affect GHI. Furthermore, the interdecadal spatio-temporal variability of GHI was studied; a successive increase was observed in the region between 1981-2010. The distribution of the variable can be linked to the cloudiness and rainfall variability that characterizes the region.

During the summer, Atlantic air masses, with a more southerly influence, penetrate the continent loaded with humidity, contributing (with the associated cloudiness) to the decrease in $\mathrm{GHI}$ in the eastern sector of the area. As they move across the continent, air masses lose moisture and cloud cover decreases, which explains GHI increase in central areas of the zone studied. On the other hand, due to the dynamics of SAMS, the $\mathrm{N}$ zone of the study area is fundamentally influenced by E-NE winds (carriers of humidity and precipitation), while the SW has greater influence of $\mathrm{W}$ winds that carry dry air masses. During winter, GHI spatial distribution presents an ascending gradient in a southeast-northwest direction, approximately perpendicular to the direction of fronts advance and to the isobaric arrangement manifested in the final phases of the most frequent winter synoptic situations. The presence of the low pressure system in the Atlantic Ocean defines descending cloud patterns in the southeast-northwest direction. The anticyclonic presence in the center of the country after the passage of cold fronts defines clear skies for the southwestern sector of the study area and, therefore, higher GHI values in these sectors. Furthermore, the Sudestada and migratory action centers associated with its formation can also be associated with GHI winter distribution in the study area.

Knowing the characteristics of insolation and the factors affecting its spatio-temporal variability in the regional context constitutes a fundamental input to promote sustainable development measures. With more than $90 \%$ of the population located in urban settlements, photovoltaic electricity production in the Pampeana region is an important measure in terms of energy diversification. The present work is the first phase in the analysis of solar climate in order to determine the potentiality of this resource.

\section{Acknowledgements}

NCEP Reanalysis data provided by the NOAA/OAR/ ESRL PSL, Boulder, Colorado, USA, from their Web site at https://psl.noaa.gov/. We acknowledge the "Physical Geography Applied to the Study of Society-Nature Interaction. Problems at Different TimeSpace Scales" research project, (24/G078) and "Solar radiation applied to climate change local management in Bahía Blanca" research project (24/ZG23), both with the subsidy of the Secretaría General de Ciencia y Tecnología, Universidad Nacional del Sur, for supporting this study.

\section{References}

Abal, G. (2012): Fundamentos de Energía Solar. Montevideo: Universidad de la República.

Aguirre, C., Flores-Aqueveque, V., Vilches, P., Vásquez, A., Rutllant, J. A., Garreaud R. (2021): Recent Changes in the Low-Level Jet along the Subtropical West Coast of South America. Atmosphere 12(4), 465, https://doi.org /10.3390/atmos12040465.

Aguirre, C., Rojas, M., Garreaud, R. D., Rahn, D. A. (2019): Role of synoptic activity on projected changes in upwelling-favourable winds at the ocean's eastern boundaries. npj Climate and Atmospheric Science 2, 44, https://doi.org/10.1038/s41612-019-0101-9.

Alessandro, A. P. (1998): Contribuciones Al Estudio de La Climatología Sinóptica En La Argentina. Universidad de Buenos Aires, http://digital.bl.fcen.uba.ar/Download /Tesis/Tesis_3091_Alessandro.pdf.

Ambrizzi, T., Pezza, A. B. (1999): Cold Waves and the Propagation of Extratropical Cyclones and Anticyclones in South America: A Synoptic-Climatological Overview. Revista Geofísica 51, 45-67.

Andrade, M. I., Laporta, P., Iezzi, L. (2009): Sequías En El Sudoeste Bonaerense: Vulnerabilidad e Incertidumbre. Revista de Estudios Geográficos 5(55), 213-231, http:// geograficando.fahce.unlp.edu.ar.

Argungu, G. M., Dabai, K. A. (2017): Application of Linear Models for Estimation of Global Solar Radiation Using Available Meteorological Parameters for Sokoto, Nigeria'. International Journal of Advances in Scientific Research and Engineering 3(11), 76-83, https://doi.org/10.7324 /IJASRE.2017.32556.

Assi, A., Mohammed, J. (2010): Estimating Global Solar Radiation on Horizontalfrom Sunshine Hoursin Abu Dhabi - UAE'. In 4th WSEAS International Conference on Energy Planning, Energy Saving, Environmental Education - 4th WSEAS International Conference on Renewable Energy Sources, edited by Ali Kallel, Abdelhamid Hassairi, Cornelia Aida Bulucea, and Nikos Mastorakis, 101-108. Kantaoui, Tunisia. www.wseas.org.

Barros, V., Gonzalez, M., Liebmann, B., Camilloni, I. (2000): Influence of the South Atlantic Convergence Zone and South Atlantic Sea Surface Temperature on Interannual Summerrainfall Variability in Southeastern South America. Theoretical and Applied Climatology 67, 123-133, https://doi.org/10.1007/s007040070002.

Bejarán, R. A., Camilloni, I. A. (2003): Objective Method for Classifying Air Masses: An Application to the Analysis of Buenos Aires' (Argentina) Urban Heat Island Intensity. Theoretical and Applied Climatology 74, 93-103, https://doi.org/10.1007/s00704-002-0714-4.

Benson, R. B., Paris, M. V., Sherry, J. E., Justus, C. G. (1984): Estimation of Daily and Monthly Direct, Diffuse and Global Solar Radiation from Sunshine Duration Measurements'. Solar Energy 32(4), 523-535, https:// doi.org/10.1016/0038-092X(84)90267-6.

Bohn, V. Y., Piccolo, M. C., Perillo, G. M. E. (2011): Análisis de Los Períodos Secos y Húmedos En El Sudoeste de La Provincia de Buenos Aires (Argentina). Revista 
de Climatología 11, 31-43, https://ri.conicet.gov.ar /handle/11336/21270.

Bruniard, E. (1981): El Clima de Las Planicies Del Norte Argentino'. Universidad Nacional del Nordeste.

Campo, A. M., Ramos, M. B., Zapperi, P. (2008): Análisis de Las Variaciones Anuales de Precipitacion En El Suroeste Bonaerense. In VII Jornadas de Geografía Física, 149-158. San Salvador de Jujuy.

Campo de Ferreras, A. M., Capelli de Steffens, A. M., Diez, P. (2004): Clima Del Suroeste Bonaerense. Bahía Blanca, Argentina: Departamento de Geografía y Turismo, Universidad Nacional del Sur.

Capelli de Steffens, A. M., Piccolo, M. C., Campo de Ferreras, A. M. (2005): Clima Urbano de Bahía Blanca. Buenos Aires: Dunken.

Capitanelli, R. (2008): Los Ambientes Naturales Del Territorio Argentino. Un Sistema Basado En La Diversidad. In Argentina: Una Visión Actual y Prospectiva Desde La Dimensión Territorial, 63-120. Buenos Aires: Emecé Editores.

Casado, A. (2013): Human Impacts and Fluvial Metamorphosis. The Effects of Flow Regulation on the Hydrology, Morphology and Water Temperature of the Sauce Grande River, Argentina. Université Blaise Pascal Clermont-Ferrand II - Universidad Nacional del Sur, Clermont-Ferrand.

Casado, A., Campo, A. M. (2019): Extremos Hidroclimáticos y Recursos Hídricos: Estado de Conocimiento En El Suroeste Bonaerense, Argentina. Cuadernos Geográficos 58(1), 6-26, https://doi.org/10.30827/cuadgeo.v58i1.6751.

Casado, A., Picone, N. (2018): Aplicabilidad de Los Datos Grillados Para El Análisis Espaciotemporal de Las Precipitaciones, Provincia de Buenos Aires (Argentina): Párrafos Geográficos 17 (1), 46-62.

Celemín, A. (1984): Meteorología Práctica. Mar del Plata: Edición del Autor.

Chiozza, E., Figueras, R. (1982): Atlas Total de La República Argentina. Tomo II. Buenos Aires: Centro Editor de América Latina.

Doyle, M. E., Vicente, R. B. (2002): Midsummer Low-Level Circulation and Precipitation in Subtropical South America and Related Sea Surface Temperature Anomalies in the South Atlantic. Journal of Climate 15 (23), 3394-3410, https://doi.org/10.1175/1520-0442(2002)015<3394:MLL $\mathrm{CAP}>2.0 . \mathrm{CO} ; 2$

Escobar, G., Vargas, W., Bischoff, S. (2004): Wind Tides in the Rio de La Plata Estuary: Meteorological Conditions. International Journal of Climatology 24, 1159-1169, https://doi.org/10.1002/joc.1026.

Fernández, M. E., Gentili, J. O., Campo, A. M. (2018): Sunshine duration analysis as a first step to estimate solar resource for photovoltaic electricity production in middle latitudes. Environmental Processes 5(2), 313-328, https://doi.org/10.1007/s40710-018-0298-3.

Ferrelli, F. (2010): La sequía 2008-2009 en el Sudoeste de la provincia de Buenos Aires, Universidad Nacional del Sur, https://doi.org/10.13140/RG.2.1.1693.9289.

Ferrelli, F. (2016): Análisis del clima local y micro-local de la ciudad de Bahía Blanca Universidad Nacional del Sur, http://repositoriodigital.uns.edu.ar/bitstream /123456789/2698/1/Tesis_Ferrelli_2016.pdf, https:// doi.org/10.30972/geo.13262123.

Ferrelli, F., Scientific, N., Bohn, V., Scientific, N., Piccolo, M. C. (2012): Variabilidad de la precipitación y ocurrencia de eventos secos en el sur de la provincia de Buenos Aires. IX Jornadas Nacionales de Geografía Física, 15-28.

Campo de Ferreras, A.M., Moresino, A. M. H., Huamantinco, S. D. (2004): Ocurrencia de sudestadas en el suroeste bonaerense. Contribuciones Científicas. Sociedad Argentina de Estudios Geográficos 16, 45-50.

Franco, J., Belmonte, S., Sarmiento, N., González, F., Discoli, C., Martini, I., Viegas, G., Barros, M. V., Chevez, P., Garrido, S., Schmukler, M., Lalouf, A., Escalante, K., González, J. (2017): Energías Renovables en Argentina: visiones y perspectivas de los actores sociales, http://energiarenovableysociedad.com/img /InformefinalPIOYPF_2017_01-06.pdf.

Gabella, J., Zapperi, P., Campo A. (2010): Distribución estacional de las precipitaciones en el Suroeste bonaerense. VIII Jornadas De Geografía Física, 1-7.

García, M. (2013): Clima urbano costero de Mar del Plata y Necochea-Quequén. BMPress.

Garreaud, R. D., Aceituno, P. (2007): Atmospheric Circulation and Climatic Variability. In T. Veblen, Y. K., A. Orme (Eds.), The Physical geography of South America, 45-59: Oxford University Press, https://doi.org /10.1093/oso/9780195313413.003.0010.

Gentili, J. O. (2012): Hidrografía del arroyo Sauce Corto aplicada al estudio de las inundaciones y anegamientos. Universidad Nacional del Sur.

Gentili, J. O., Gil, V. (2013): Variabilidad temporal de las precipitaciones en vertientes opuestas del Sistema de Ventania, Buenos Aires, Argentina. Revista Universitaria de Geografía 22(1), 147-166.

Gil, V., Gallardo, C., Hagel, E., Tejeda, C., Gaertner, M. A., Sanchez, E., de Castro, M. (2015): Analysis of interannual variability of sunshine hours and precipitation over Peninsular Spain. Renewable Energy 83, 680-689, https://doi.org/10.1016/j.renene.2015.05.001.

Gómez-Tagle Chávez, A., Chavez Huerta, Y. (2004): Cálculo de la distribución espacial de la insolación potencial en el terreno empleando MDE en un ambiente SIG. Investigaciones Geográficas, Boletín Del Instituto de Geografía UNAM 55, 7-22, https://doi.org/10.14350 /rig.30108.

González, M., Barros, V. R. (2001): La precipitación en Argentina Subtropical y su relación con el Monzón Sudamericano. In A. Pérez Cueva, E. López Baeza, J. Tamayo Carmona (Eds.), El tiempo del clima, 565-574: Garmas Impresores.

Grimm, A. M. (2011): Interannual climate variability in South America: impacts on seasonal precipitation, extreme events, and possible effects of climate change. Stochastic Environmental Research and Risk Assessment 25(4), 537-554, https://doi.org/10.1007 /s00477-010-0420-1.

Grimm, A. M., Barros, V. R., Doyle, M. E. (2000): Climate Variability in Southern South America Associated with El Niño and La Niña Events. Journal of Climate 13(1), 35-58, https://doi.org/10.1175/1520-0442(2000)013<0035:CVI SSA > 2.0.CO;2.

Grossi Gallegos, H. (1997): Evaluación a nivel de superficie de la radiación solar global en la República Argentina. Universidad Nacional de Luján.

Gueymard, C. A., Wilcox, S. M. (2011): Assessment of spatial and temporal variability in the US solar resource from radiometric measurements and predictions from models using ground-based or satellite data. Solar Energy 85(5), 
1068-1084, https://doi.org/10.1016/j.solener .2011.02.030.

Habte, A., Stoffel, T., Perez, R., Myers, D., Gueymard, C., Philippe Blanc, 6 and Stefan Wilbert. (2017): Overview of Solar Radiation Resource Concepts. In M. Sengupta, A. Habte, C. Gueymard, S. Wilbert, D. Renné, T. Stoffel (Eds.), Best Practices Handbook for the Collection and Use of Solar Resource Data for Solar Energy Applications: Second Edition (2.1-2.22): NREL.

Hay, J. E. (1979): Calculation of monthly mean solar radiation for horizontal and inclined surfaces. Solar Energy 23(4), 301-307, https://doi.org /10.1016/0038-092X(79)90123-3.

Hay, J. E. (1984): An assessment of the mesoscale variability of solar radiation at the earth's surface. Solar Energy 32(3), 425-434, https://doi.org/10.1016 /0038-092X(84)90287-1.

Hermosillo Villalobos, J. J., Gudiño Ayala, D., Mendoza Ramírez, M. (1995): Notas sobre el curso de Energía Solar. Instituto Tecnológico y de Estudios Superiores de Occidente, http://www.solartronic.com/download /curso_iteso.pdf

Hoffmann, J. A. J. (1992): The continental atmospheric pressure and precipitation regime of South America. Erdkunde 46, 40-51, https://doi.org/10.3112 /erdkunde.1992.01.04.

Inzunza, J. (2012): Circulación de la atmósfera. In Meteorología Descriptiva, 225-260: Universidad de Concepción.

Jerez, S., Trigo, R. M. (2013): Time-scale and extent at which large-scale circulation modes determine the wind and solar potential in the Iberian Peninsula. Environmental Research Letters 8, 044035, https://doi.org/10.1088 /1748-9326/8/4/044035.

Liebmann, B., Vera, C. S., Carvalho, L. M. V., Camilloni, I. A., Hoerling, M. P., Allured, D., Barros, V. R., Báez, J., Bidegain, M. (2004): An observed trend in central south american precipitation. Journal of Climate 17(22), 4357-4367, https://doi.org/10.1175/3205.1.

Linares-Rodríguez, A., Ruiz-arias, J. A., Pozo-Vázquez, D., Tovar-Pescador, J. (2011): Generation of synthetic daily global solar radiation data based on ERA-Interim reanalysis and artificial neural networks. Energy 36(8), 5356-5365, https://doi.org/10.1016/j.energy .2011.06.044.

Löf, G. O. G., Duffie, J. A., Smith, C. O. (1966): World distribution of solar radiation. Solar Energy 10(1), 27-37, https://doi.org/10.1016/0038-092X(66)90069-7.

Lohmann, S., Schillings, C., Mayer, B., Meyer, R. (2006): Long-term variability of solar direct and global radiation derived from ISCCP data and comparison with reanalysis data. Solar Energy 80, 1390-1401, https://doi.org /10.1016/j.solener.2006.03.004.

Marengo, J. A., Liebmann, B., Grimm, A. M., Misra, V., Silva Dias, P. L., Cavalcanti, I. F. A., Carvalho, L. M. V., Berbery, E. H., Ambrizzi, T., Vera, C. S., Saulo, A. C., NoguesPaegle, J., Zipser, E., Seth, A., Alves, L. M. (2012): Recent developments on the South American monsoon system. International Journal of Climatology 32(1), 1-21, https://doi.org/10.1002/joc.2254.

Matuszko, D. (2012): Influence of cloudiness on sunshine duration. International Journal of Climatology 32, 1527-1536, https://doi.org/10.1002/joc.2370.

Mendes, D. (2006): Regimes de circulação no Atlântico Sul e sua relação com a localização e intensidade de sistemas ativos e com o balanço de vapor na região. Universidad de Lisboa.

Mendonça, M. (2017): Monzón Sudamericano: La integración de la circulación amazónica y altiplánica y las variabilidades climáticas del Altiplano Andino Chileno. Dialogo Andino 54, 21-30, https://doi.org/10.4067 /S0719-26812017000300021.

Minetti, J. L. (2007): La respuesta del Anticiclón Del Pacífico Sur en la costa de Chile frente al cambio climáticoimpactos. Boletín Geográfico, 30(1), 9-22.

Oke, T. R., Mills, G., Christen, A., Voogt, J. A. (2017): Urban Climates. Cambridge University Press, https://doi .org/10.1017/9781139016476.

Patton, C. P., Alexander, C. S., Kramer, F. L. (1978): Curso de Geografía Física. VICENS universidad.

Penalba, O. C., Vargas, W. M. (2004): Interdecadal and interannual variations of annual and extreme precipitation over central-northeastern Argentina. International Journal of Climatology 24, 1565-1580, https://doi.org/10.1002/joc.1069.

Pezza, A. B., Ambrizzi, T. (2003): Variability of Southern Hemisphere Cyclone and Anticyclone Behavior: Further Analysis. Journal of Climate 16(7), 1075-1083, https:// doi.org/10.1175/1520-0442(2003)016<1075:voshca $>2.0 . \mathrm{co} ; 2$.

Piccolo, M. C., Capelli de Steffens, A. M., Campo de Ferreras, A. M. (2002): La sequía del año 1995 en el sur de la región pampeana argentina. In J. Lugo, M. Inbar (Eds.), Desastres Naturales en América Latina, 189-206.

Pizarro, H., Rodríguez, P., Bonaventura, S. M., O’Farrell, I., Izaguirre, I. (2007): The sudestadas: a hydrometeorological phenomenon that affects river pollution (River Luján, South America): Hydrological Sciences Journal 52(4), 702-712, https://doi.org/10.1623 /hysj.52.4.702.

Pozo-Vázquez, D., Tovar-Pescador, J., Gámiz-Fortis, S. R., Esteban-Parra, M. J., Castro-Díez, Y. (2004): NAO and solar radiation variability in the European North Atlantic region. Geophysical Research Letters 31, 1-4, https:// doi.org/10.1029/2003GL018502.

Raichijk, C., Grossi Gallegos, H., Righini, R. (2006): Variabilidad espacial de la heliofanía (duración de la insolación) en la Pampa Húmeda Argentina, Uruguay y sur del Brasil. Energías Renovables y Medio Ambiente 19, 33-37.

Ramirez Camargo, L., Altamirano, M., Belmonte, S., Dorner, W. (2015): Comparación de fuentes satelitales, de re-análisis y métodos estadísticos para el mapeo de la radiación solar en el Valle de Lerma (Salta-Argentina): Avances En Energías Renovables y Medio Ambiente 19, 11.19-11.30.

Ramos, M. B., Campo, A. M. (2008): Caracterización de estados de tiempo en el suroeste bonaerense, Argentina. Revista de Geografía Norte Grande 40, 85-97, https:// doi.org/10.4067/S0718-34022008000200006.

Román, R., Bilbao, J., de Miguel, A. (2014): Reconstruction of six decades of daily total solar shortwave irradiation in the Iberian Peninsula using sunshine duration records. Atmospheric Environment 99, 41-50, https://doi .org/10.1016/j.atmosenv.2014.09.052.

Romero Aravena, H., Mendonça, M., Méndez Díaz, M., Smith Guerra, P. (2011): Multiescalaridad, relaciones espaciales y desafíos ecológico-sociales de la climatología sudamericana. El caso del Desierto de Atacama 8, 7-29. 
Rubí Bianchi, A., Cravero, S. A. C. (2010): Atlas climático digital de la República Argentina. INTA.

Saha, S., Moorthi, S., Pan, H. L., Wu, X., Wang, J., Nadiga, S., Tripp, P., Kistler, R., Woollen, J., Behringer, D., Liu, H., Stokes, D., Grumbine, R., Gayno, G., Wang, J., Hou, Y. T., Chuang, H. Y., Juang, H. M. H., Sela, J., ... Goldberg, M. (2010): The NCEP climate forecast system reanalysis. Bulletin of the American Meteorological Society 91(8), 1015-1057, https://doi.org/10.1175/2010BAMS3001.1.

Sarochar, R. H. (2018): Distribución y caracterización de la precipitación convectiva y estratiforme en la Pampa Húmeda Argentina. Congremet XIII, 1-3.

Sarochar, R. H., Ciappesoni, H. H., Ruiz, N. E. (2005): Precipitaciones convectivas y estratiformes en la Pampa Húmeda: una aproximación a su separación y aspectos climatológicos de ambas. Meteorologica 30(1-2), 77-88.

Scarpati, O. E., Capriolo, A. D. (2013): Droughts and floods in Buenos Aires province (Argentina) and their space and temporal distribution. Investigaciones Geograficas 82(82), 38-51, https://doi.org/10.14350/rig.31903.

Schroeder, T. A., Hember, R., Coops, N. C., Liang, S. (2009): Validation of solar radiation surfaces from MODIS and reanalysis data over topographically complex terrain. Journal of Applied Meteorology and Climatology 48(12), 2441-2458, https://doi.org/10.1175/2009JAMC2152.1.

Scian, B. (2010): Clima - Bahía Blanca y Sudoeste Bonaerense. In J. D. Paoloni (Ed.), Ambiente y Recursos Naturales del Partido de Bahía Blanca. Clima, Geomorfología, Suelos y Aguas, 27-83: EdiUns.

Sengupta, M., Habte, A., Gueymard, C., Wilbert, S., Renné, D. (2017): Best Practices Handbook for the Collection and Use of Solar Resource Data for Solar Energy Applications: Second Edition, http://www.nrel.gov /publications.

Servicio Meteorológico Nacional. (2010): Inundaciones, Sudestadas y crecientes inundaciones repentinas. Boletín informativo $\mathrm{N}^{\circ} 2$, http://smn.cna.gob.mx/es /informacion-climatologica-ver-estado?estado=zac.

Sinclair, M. R. (1996): A climatology of anticyclones and blocking for the Southern Hemisphere. Monthly Weather Review 124, 245-263.
Tomson, T., Hansen, M. (2010): Fast changes of the solar irradiance. Estonian Journal of Engineering 16, 176-183, https://doi.org/10.3176/eng.2010.2.06.

Urban, G., Migała, K., Pawliczek, P. (2017): Sunshine duration and its variability in the main ridge of the Karkonosze Mountains in relation to with atmospheric circulation. Theoretical and Applied Climatology 131, 1173-1189, https://doi.org/10.1007 /s00704-017-2035-7.

Vera, C., Higgins, W., Amador, J., Ambrizzi, T., Garreaud, R., Gochis, D., Gutzler, D., Lettenmaier, D., Marengo, J., Mechoso, C. R., Nogues-Paegle, J., Silva Dias, P. L., Zhang, C. (2006): Toward a unified view of the American monsoon systems. Journal of Climate 19(20), 4977-5000, https://doi.org/10.1175/JCLI3896.1.

Vera Mella, N., Baldasano Recio, J. M. (2005): Atlas climático de irradiación solar a partir de imágenes del satélite NOAA aplicación a la Península Ibérica. Universitat Politècnica de Catalunya.

Weber, G. R. (1994): On the seasonal variation of local relationships between temperature, temperature range, sunshine and cloudiness. Theoretical and Applied Climatology 50(1-2), 15-22, https://doi.org/10.1007 /BF00864898.

Zapperi, P. A. (2012): Hidrografía Urbana de Bahía Blanca. Departamento de Geografía y Turismo, Universidad Nacional del Sur.

Zapperi, P. A., Casado, A., Gil, V., Campo, A. M. (2006): Caracterización de las precipitaciones invernales en el Suroeste bonaerense. In N. Cazzaniga M. Vaquero (Eds.), Ambiente natural, campo y ciudad: Estrategias de uso y conservación en el Sudoeste Bonaerense 63-68: EdiUNS.

Zapperi, P., Ramos, M. B., Gil, V., Campo, A. M. (2007): Caracterización de las precipitaciones estivales en el Suroeste bonaerense. Contribuciones Científicas GAEA 19, 483-491, http://gaea.org.ar/contribuciones /contribuciones_vol19_Zapperi-Ramos-Gil-Campo.pdf.

Zhou, J., Lau, K. M. (1998): Does a monsoon climate exist over South America? Journal of Climate 11(5), 1020-1040, https://doi.org/10.1175 /1520-0442(1998)011<1020:DAMCEO>2.0.CO;2. 